\title{
Theatre and Language
}

\section{Introduction}

\section{LAURA GRÖNDAHL \& ANNA WATSON}

The theme "Theatre and Language" opens to many directions, as this present issue of Nordic Theatre Studies proves. The choice of the theme was motivated by what we see as the importance of successful communication in increasingly multicultural and globalizing societies: we are facing an urgent need of understanding each other across cultural borders and manners. Now, one and half years after releasing the call for papers, this demand seems all the more important, and even overwhelming. We have not only witnessed violent conflicts causing the worst refugee crisis since the Second World War; we have also experienced the effects of "post-truth" politics and populism, making use of social media bubbles in order to turn lies into facts. It is as if we had lost our ability to talk and listen to other people in decent, fair-minded ways.

Hannah Arendt writes in her book The Human Condition that speech makes humans into political beings, who "can experience meaningfulness only because they can talk with and make sense to each other and to themselves." In order to create a common table, around which we can peacefully solve our conflicts and make the differing viewpoints comprehensible, we need language.

1. Arendt $1998,3-4$. 
We also need to understand, how this everyday - "built-in" - communication technique works. The capability to speak is in itself an intriguing mystery. The language system allows us to create an infinite number of complex meanings by combining symbolic signs according to different grammatical rules. Theorists are not unanimous to what extent this capability is based on: a genetically coded competence, primary bodily experiences or learned cultural structures. What probably everybody agrees on; is that speech and writing have contributed to the human evolution and history more than any other innovation.

The language both unites and separates us from each other. The choice of spoken language is a highly political question, and theatre has frequently served as a site for cultural struggles over linguistic hegemonies. Language is an inherent part of the social power structures: who is allowed to speak, on what subject and on which terms? The right to speak one's native tongue has traditionally been constitutive for the formation of local and national identities. Respectively, the control of correct and appropriate speech is an efficient way of using power, producing and maintaining discursive norms. A person's accent, pronunciation and vocabulary are part of his/her social, racial and gendered habitus, which determines his/her status as a speaking subject.

Wenche Torrissen is looking deeper into such issues in her article on the Hålogaland Theatre in Tromsø. She shows how performances of canonized classic plays in a local vernacular dialect contributed to the positive revaluation of the northern regions of Norway. Building on Pierre Bourdieu's sociological theories she examines the historical formation of the linguistic habitus, and its significance for the people's social status and self-esteem. The article focuses on the 1970s, when Hålogaland Theatre successfully struggled to move the production and control of local culture from the capital Oslo, to the inhabitants of the Northern districts.

Even if we speak the same language, we never understand the words exactly in a same way. There is also a continual possibility for misinterpretations, and there always remains a "surplus", a vague touch of something that the words cannot reach. According to poststructuralist philosophies, we can never get outside of the language, which is a never-ending process of constructing and deconstructing meanings.

Taking another viewpoint, many theatre makers and scholars suggest, that the live experience of a performance can create common understanding across different cultures and communities, because it functions prior to or bey- 
ond of verbal conceptualization. Phenomenologists have focused their attention to the immediate perception and holistic encountering between humankind and the world, instead of seeing language as clearly interpretable systems of signs. Psychoanalysis attempts to reach deeper levels of consciousness, which are rather hidden than expressed by ordinary speech. From this perspective, the rationalizing language can also be seen as a blockage that prevents one's connection to his/her own psyche. The cognitive approach to theatre suggests for its part that conceptual thinking is in itself based on primary metaphors, generated through bodily interaction with the environment in early infancy. Following that path, the verbal language is not opposite to pre-conscious bodily experiences but has developed out of them. What seems common to all these orientations is the question about universal conditions of human thinking: what unites us all, independently of culturally differing languages? How do these universal human aspects manifest themselves in theatre, and can we make them accessible by means of a performance experience?

Jeffrey Kaplan asks in his article, how a bodily dance practice may help us to understand the function of language. He researches the tradition of northern story telling by means of a self-reflective analysis of performing the medieval epic poem Beowulf. He explored the sounds and rhythms of the ancient language by means of dance rehearsals, comparing his method to experimenting archaeology. The mnemonic techniques, rhythms and alliterations of the old verses carried embodied patterns, which enabled him to recreate the spoken text and reveal aspects that cannot be traced by merely literal analyses. In his approach, the language contains forgotten bodily knowledge that can be revived through artistic techniques.

There are on estimation at least 6000 different languages in the world.2 A translation can never preserve text contents completely unaltered, no matter how well it is done. Something is always lost and added in the process. A translation is not only a linguistic process but also a negotiation between the source and target cultures: should the foreign text conform to the domestic readers' mind-set concealing the cultural differences, or should it maintain its strangeness?

The domestication of translated plays may often be vital for their success at the theatre, as Rebecca Flynn shows in her article, which discusses Thomas Antsey Guthrie's alias F.Antsey's comic renditions of Ibsen's well-known 
plays. Flynn suggests that parody can serve as a translation from the serious, Nordic texts to the British audiences. She analyses Antsey's versions of Rosmersholm, A Doll's House (Nora; or the Bird Cage) Hedda Gabler, and The Master Builder (Pill-Doctor Herda). They are all plays where a new, emancipated woman is given a central focus. According to Flynn, the comical treatment did not dismiss Ibsen's original ideas, but domesticated the plays and made the contents more accessible and digestible to British readers and spectators.

Speech is not only about text and contents; it is also a performative act that has consequences in the social reality. Words can do things, as J.L.Austin suggested in his famous speech act theory. Building on this framework, Laura Gröndahl examines contemporary Finnish verbatim-theatre in her article. She asks, how the presentation of recorded documents on stage constitutes knowledge and beliefs about reality. After theorizing the use of verbatim techniques in the documentary genre through international examples, she discusses five recent Finnish performances as case studies of contemporary political theatre, which combines postmodern relativist premises to the will of having an influence on social reality.

The issue of language is not only approached in different ways in all the above-described articles, which all are part of the language-theme section. The topic seems to be present, also, in the articles of the open section, since after all, theatre is always about communication.

The joint article by Daniel Meyer-Dinkgräfe and Anita Hammer suggests that philosophical thinking happens through immediate experiences, and not only in abstract speculation and reasoning. Formulating their ideas as a dialogue, they ask, how theatre can serve as a creative tool for expressing nonverbal philosophical experiences. The authors take examples from Scandinavian performance practices, and focus more closely on the German dancer-philosopher Aurelia Baumgartner.

Keld Hyldig continues the discussion of theatre as philosophy by analysing Romeo Castellucci's staging of Friedrich Hölderlin's Oedipus the Tyrant, as a medium for epistemic confrontation between religious and rational thinking. Hyldig introduces the concept of "philosophical theatricality", based on the simultaneity of fictional representations and performative presence in theatre. In his analysis, Castellucci's performance turned this relationship between fiction and physical reality into a philosophical issue by using meta-theatrical elements. 
In regard to language, listening is as important as speaking. Yet, the reception is a far less studied area than the production of performances. The collaborative article by Anna Lawaetz, Christina Østerby and Nina Gram presents an audience research project, which examines how the environment changes the ways in which the spectators articulate their performance experiences in hindsight. Audience-members of The Royal Danish Theatre were invited to group-discussions in different spaces after the performance, and the settings were recorded and analysed.

In terms of artistic research, theatre can be seen as a practice that produces knowledge differently from traditional scholarly discourses. In the freeform essay section, Lars Henning presents an experimental actors' training method, which is built on the use of English as common language in a multicultural ensemble. Describing a production of Charles Mee's Orestes 2.0 he suggests that the English spoken by non-native speakers in the group, serves as a common playground that creates new possibilities of how to use language.

Jurate Baranova's review of the book Deleuze and Beckett, edited by S.E.Wilmer and Audroné Žukauskaitè, ends the issue, adding one more layer to the philosophical discussions. Like the Deleuzian rhizome, the theme of language appears as network of countless entrances and connections, which cannot be neatly categorized. It certainly calls for further research and artistic interventions, only a fraction of which could be touched on these pages.

We wish to thank most warmly all authors and peer reviewers for their valuable contributions, and Steve Smith for proof reading of all the texts. This is now the second issue of Nordic Theatre Studies that is solely published online. In this respect we are very grateful to Aarhus University Library for providing us with the platform, which enables a wide distribution of an open access publication.

\section{References}

Arendt, Hannah 1998/1958. The Human Condition. Chicago \& London: The University of Chicago Press.

http://www.kotus.fi/kielitieto/kielet accessed 5.1.2017 